\title{
Just in Time: Temporality and the Cultural Legitimation of Law
}

\author{
Carol J. Greenhousef
}

\section{Introduction: Time, Culture, ANd Society}

This Article is about the relationship between cultural conceptions of time-"social time"-and the organization and management of legal institutions. As an idea, time has profound consequences in its capacity to encode and systematize otherwise disparate and unreferenced events and relationships. Concepts of time vary widely around the world, and Western ideas about time-including the conventional formulation that time moves in a straight line from past to present, through one's own lifetime-acquired shape and force entirely apart from the scientific "discovery" of time. "This Article focuses in particular on Western ideas about time, and, even more particularly, on the ways in which temporality suffuses popular understandings of law. Specifically, after some preliminary ethnological and historical discussion, it offers an analysis of the ways in which specific indeterminacies in Western notions of time are worked out in the legal context. Its central thesis is that temporality and legality are conceptually fused in the West through their mutual implications of a total order in relation to which social life acquires meaning.

Among the ways in which cultural systems differ-and anthropology is the study of the significance of cultural difference-are the ways in which they engage different temporal logics as fundamental rationales of social organization. Social structure, which preserves essential principles, purposes and institutional forms over the generations, is itself a kind of timekeeping. ${ }^{2}$ Anthropologists and scholars in other disciplines have longstand-

t Associate Professor of Anthropology, Cornell University. An earlier version of the first two sections of this article was presented to the Anthropology Department Colloquium of Cornell University in April, 1988. Any research project that has been in the making for as long as this one benefits from numerous conversations; mine is no exception, and I express appreciation here for my colleagues and students at Cornell. I feel particularly indebted to Professors A.C. Aman, James Boon and Nancy Lutz. The preliminary research for the larger project from which this article derives was funded by a summer stipend from the National Endowment for the Humanities in 1983. I gratefully acknowledge their support.

1. See J.G.A. Pocock, Politics, Language and Time: Essays on Political Thought and History 233-72 (1989) (discussing time as social and historical questions and "geochronic" or "cosmochronic" times as scientific concerns).

2. See Evans-Pritchard, Nuer Time-reckoning, 12 AFr. 189-216 (1939); Fortes, Time and Social Structure: An Ashanti Case Study, in Social Structure: Studies Presented to A. R. RadClifFE-Brown 54 (M. Fortes ed. 1949). 
ing interests in the connections between social structures and the temporalities they involve. When sociologists Sorokin and Merton ${ }^{3}$ coined the term "social time," they sought an idiom that would capture the multiple meanings of time beyond the technology of time-reckoning. The idea of "social time" provides one starting point for this Article.

A second starting point is in the ethnology of law. Ethnology is the comparative study of sociocultural systems. The ethnology of law and academic law share a common intellectual ancestor in Sir Henry Maine, whose Ancient Law explores the sources and meanings of legal innovation in Roman society and culture. ${ }^{4}$ His modern inheritors on the anthropological side are, in general, concerned with the construction and reproduction over time of normative orders and their social significance in contemporary societies. ${ }^{5}$ As the cross-cultural sweep of anthropological studies of law widens, scholars are increasingly confronted with the fundamentally different meanings and arrangements that social order entails in the modern world. Simply stated, notions of what law is and how it operates are far from universal. While this observation adds to the interest of ethnological studies, it also confounds the question of where the starting point of productive comparison might lie. ${ }^{6}$

These two points-the social nature of time and the cultural ramifications of law-converge in issues of the regulation of social processes. In practice, this means that every culture has some constantly dynamic code (or, more probably, a set of rival codes) for controlling competition, contradiction, and irony. In effect, such codes are systems of accountability, for it is through notions of accountability that societies formally attach social meaning to individual experience. To this we must add the observation that social systems never sit still, but constantly improvise, negotiate, contest, celebrate, and lament change. Where institutionalized law exists, it claims for itself many formal roles in managing normative change.

Time is about many things, but it is always ironic; it always implies that there is meaning beyond lived experience that nevertheless constitutes a commentary on lived experience. Time, whatever its "shape," calls forth loyalties of various kinds: to God, land, descent group, king, nation, employer, one's children, and so on. Concepts of time might be dominated by

3. Sorokin \& Merton, Social Time: A Methodological and Functional Analysis, 42 AM. J. Soc. 615-29 (1937).

4. H. Maine, Ancient Law (1986) (1st ed. 1861).

5. For synoptic views of this literature, see Collier, Legal Processes, in Annual Review of ANTHropology 121; Moore, Law and Anthropology, in BIENNIAL Review of ANTHRopology 1969, at 252-300 (B. Siegel ed. 1970); Nader, The Anthropological Study of Law, 67 AM. ANTHRoPologist 3 (1965); Snyder, Anthropology, Dispute Processes and Law: A Critical Introduction, 8 BRIT. J.L. \& Soc'y 141 (1981); Starr \& Collier, Introduction: Dialogues in Legal Anthropology, in History AND POWER in THE STUDY OF LAw 1-28 (J. Starr \& J. Collier eds. 1989)

6. See generally J. Comaroff \& S. Roberts, Rules and Processes: The Cultural Logic of Dispute in an African Context 3-21 (1981); G. Geertz, Local. Knowledge 167-234 (1983). 
one "shape" or another (e.g., a circle, line, or pendulum motion) or by no shape at all (later, I call one version of shapeless time "all-times"), but all concepts of time are flexible, permeable, and capable of proliferation. Thus, to refer to time's form is inevitably merely a shorthand for referring to cultural strategies for managing the multiple forms of time that are simultaneously available in any single social context. ${ }^{7}$ For the same reason, social structures are never permanently fixed or free of internal contradictions that are potentially undermining.

Time could never be socially neutral, even where it appears to Western eyes to be closest to the "givens" of birth and death. Time is not everywhere thought to be about the interval between birth and death, ${ }^{8}$ nor everywhere about "lifetimes" or even individuals. ${ }^{\circ}$ The ethnological literature shows that many concepts of time may be immanent in any single social system, and even in any single situation. Temporal discourse varies sometimes with age ${ }^{10}$ and gender, ${ }^{11}$ sometimes with status, ${ }^{12}$ and, generally, with differing forms of social participation. Institutions that regulate social change must also, therefore, regulate the play and contestation of the multiple temporal logics that inhere in situations, and make temporal commitments themselves. Thus, the "shapes" of time are not inscribed as fixed geometric blueprints in a culture's mentalité, but are contested, negotiated, defended, and transformed in the juxtaposition of personal and institutional forms that comprise social life anywhere.

To put this more directly: "We" moderns are supposed to know that time is "really" linear and infinitely so. We are supposed to know that time is about motion, change, mortality, and progress. We are supposed to know that linear time rationalized the periodicity of cyclical time and lifted the veils of timelessness from the now-visible face of human experience, and that the clock is the essential technology of modern life. ${ }^{13}$ But "we" have also devised a strategy for resisting linear time: we imagine

7. One of the premises of this article is that time concepts are always implicitly multiple. In some contexts, the simultaneity of explicitly competing or divergent temporal forms makes an interesting subset of the anthropological literature. See C. Geertz, Person, Time, and Conduct in Bali, in ThE Interpretation of Cultures 360 (1973); A. Ortiz, The Tewa World (1969) (on the Tewa Pueblos of New Mexico); LeGoff, Au Moyen Age: Temps de l'Eglise et Temps du Marchand, 15 ANNALEs: E.S.C. 417 (1960) (on medieval Europe); Turton \& Ruggles, Agreeing to Disagree: The Measurement of Duration in a Southwestern Ethiopian Community, 19 CuRRENT ANTHRopologY 585 (1978) (on tribal Ethiopians).

8. The dreamtime of the Australian aborigines is not. See, e.g., W. STANnER, White MAN Got No Dreaming: EsSAYs 1938-1973, at 23 (1979).

9. Time is about social collectivities among the Merina. See, e.g., Bloch, Death, Women and Power, in Death and the Regeneration of Life 211 (M. Bloch \& J. Parry eds. 1982).

10. See, e.g., H. Hazan, The Limbo People 89-117 (1980).

11. See, e.g., L. Doob, Patterning of Time (1971).

12. See, e.g., LeShan, Time Orientation and Social Class, 47 J. Abnormal Soc. Psychology 589-92 (1952).

13. See generally S. Toulmin \& J. Goodfield, The Discovery of Time (1965); Goody, Time: Social Organization, in 16 INTERNATIONAL ENCYClOPEdia OF THE SOCIAL SGIENCES 30 (D. Sills ed. 1968). 
that there exist people not preoccupied with change; we are supposed to know that some of them are happier, more sociable, more provincial, more attuned to nature and less skeptical of their rituals. ${ }^{14}$ If we are romantics, we imagine ourselves experiencing this liberation in love, faith, or travel to exotic places. If we are post-moderns, though, we also know that we are not supposed to think this. ${ }^{15}$ The difficulty of developing intellectual strategies for dismantling the privileges of linear time cross-culturally and, even more so, in the examination of more familiar cultural terrain, is compounded by such contemporary Western engagements with the idea of time.

\section{LINEAR Time}

The idea of linear time that now dominates public life in the West (and elsewhere) was not indigenous to the West. Linear time came to Europe with Christianity. ${ }^{16}$ It was the concern of specialists-theologians-and became a popular idea by a long, slow, and interesting process. European conceptions of time underwent a major transformation beginning in the late twelfth century. It was then that the popularization of linear time was greatly accelerated by a wide variety of changes in thought and public life. ${ }^{17}$ The European invention of the mechanical clock (though this was not the first mechanical clock) in 1354 gave impetus and definition to new ideas about time. ${ }^{18}$

The expansion of Christianity into Europe brought with it two ideas about time that had long roots in Jewish and autochthonous Christian tradition: first, the origin of time in Greation, and second, the end of time in a Day of Judgment. The linearity of time derives simply from the geometric connection between these two endpoints. ${ }^{19}$ These arrived as new ideas to Europe, and it is difficult to know how they affected ordinary people as they encountered them in the long process of Europe's conversion to Christianity. ${ }^{20}$

14. See generally Bloch, The Past and the Present in the Present, 12 MAN 278-92 (1977).

15. See J. Fabian, Time and the Other: How Anthropology Makes Its Object (1983).

16. See LeGoff, supra note 7. The idea of linear time as the segment between creation and Judgment Day was initially a theological concern, and gradually became laicized. O. CullmanN, Christ and Time: The Primitive Christian Conception of Time and History 51-60 (F. Filson trans. 1964).

17. See, e.g., J. Huizinga, The Waning of the Mrdole Ages (1924) (new humanism and industrial workshops).

18. See L. Mumford, Technics and Civilization 13 (1934).

19. See O. CullmanN, supra note 16 , at 51 .

20. Goody's analysis of changes in family structure and inheritance as a result of early Church conversion efforts beginning in the fourth century suggests that local populations responded to Church doctrine fairly quickly. J. Goody, The Development of the Family and Marriage in Europe 33, 44-46 (1983). But other social historians suggest that the idea of one's own lifetime as personal property came much later. E. Ladurie, Montaillou (1978); J. LeGoff, Pour un Autre Moyen Age: Temps, Travail et Culture en Occident (1977); Thompson, Time, Work-Discipline and Industrial Capitalism, 38 PAST \& PRESENT 56-97 (1967). This is not necessarily a contradiction, in that there is no reason to think that the implications of linear time were fully worked out or unchang- 
The early theologians wrote about time as "a segment of eternity"; eternity is "endless time."21 Time was believed to belong to God, a belief which had numerous practical consequences as well as theoretical ones. ${ }^{22}$ The keystone of medieval philosophy was the proposition that God is not only the unique "total being" (totum esse) but also the unique "true being" (verum esse); hence, the visible, sensible world was by definition (since God monopolizes all authenticity) "mere appearance."23 Time, which was limited to the world of humankind, represents this incompleteness in this worldview. Individuals could aspire to completion only in salvation, that is, in joining God. God, always (and uniquely) total and true, existed outside of time, since there was nothing else that he could become, or could have been. Thus, the social logic of linear time took shape.

Late medieval Christianity was by no means a single entity, ${ }^{24}$ but historians stress the prevalence and persistence of ideas of time and eternity ${ }^{25}$ All of time was the history of salvation; therefore, the very idea of duration was charged with sacred significance. ${ }^{26}$ Linear time became the constant marker of the contingent and incomplete nature of human society and of every individual's life. ${ }^{27}$ The advancement of time, always toward Judgment Day, represented the advancement of human perfectibility, always relative to the perfect completeness of God. Time was "a certain mode of existence proper to contingent things, unable to realize themselves all at once in the permanence of a stable present." ${ }^{\text {28 }}$ The instant was drenched in the poignancy of impossibility: the impossibility of refusing the struggle for perfection, and the impossibility of succeeding in it. This irony became the very meaning - the enduring meaning-of the idea of a lifetime. ${ }^{28}$

ing (they continue to be worked out and to change now), or that they were experienced simultaneously.

21. See O. Cullmann, supra note 16, at 62-63; see also LeGoff, supra note 7, at 419.

22. See J. LeGofF, La Civilisation de L'Occident MÉdiéval 169-248 (1965); R. Tawney, Religion aNd the Rise of Capitalism (1962).

23. See E. Gilson, The Spirit of Medieval. Philosophy 64 (A.H.C. Downes trans. 1940).

24. See G. Leff, Heresy in the Later Middle Ages: The Relation of Heterodoxy to DISSENT C. 1250 -C. 1450 , at 26 (1967).

25. See J. LEGorf, supra note 22, at 211-12; Dales, Discussions of the Eternity of the World During the First Half of the Twelfth Century, 57 SPEculum 495-508 (1982).

26. See LeGoff, supra note 7, at 420 .

27. See E. GiLSON, supra note 23, at 385.

28. Id.

29. However great the significance and anxiety about the impending day of judgment, ordinary medieval Europeans were unconcerned with time-keeping and recording time, see $1 \mathrm{M}$. BLOCH, FEUDal. SOCIETY ch. 5, $\$ 1$ (1964); M. GILMORE, THE WORLD OF HumanisM 1453-1517, at 201 (1952); E. LADURIE, supra note 20; J. LEGofF, supra note 22, at 222, though medieval time-keeping methods are not well understood today. Wolf, Le Temps et Sa Mesure au Mojen Age, 17 AnNALES: E.S.C. 1141-45 (1962). The idea of life as a measurable property received an incalculable impetus from the invention of the mechanical clock in the middle of the fourteenth century. L. MUMFORD, supra note 18 , at 14 . Although the inspiration for this innovation may have been the needs of clerics, id. at 12 , its widespread use facilitated the laicization of time, J. LEGoFF, supra note 20 , at 67 . The clock rapidly became an urban phenomenon, a key symbol of secular power. Debates over the connection between forms of power and technologies of time-reckoning suggest that the connection is con- 
Eventually, clocks moved from steeples to palaces and town halls, as potent symbols of dominion. The ticking clock was not only a memento mori, but a reminder of the ownership of time. The fact that debates over wages, interest payments and secular government in general took place in these terms underscores the extent to which linear time calls forth a declaration of the ultimate instrumentality of time in social terms. ${ }^{30}$ Linear time is time with a purpose: a time-for-the-sake-of-God, -state, -shop, self, among other possibilities. The linearity of time reproduces both the cry for redemption and redemption's form in its fundamental proposition that the individual can find completion only by participating in a cosmic order-through social institutions that await the end of time.

\section{The Indeterminacies of Linear Time}

One way of summing up this discussion of linear time in Europe is to say that linear time's most powerful claim is that of its own redemptive power in relation to an individual's life (for example, fulfillment always implies a passage of time in this worldview). There is where the redemptive promise of linear time lies. There is where linear time provides a reservoir of symbols with which the legitimacy of hierarchies can be defended and reproduced. But there is precisely where linear time must defend itself conceptually, since any life entails multiple and simultaneous engagements involving competing priorities and loyalties. Linear time intrinsically demands a single principle of selection (or a single hierarchy of principles; for example, a subject simultaneously serves the king and God, because the king serves God), but real life is not so neatly arranged.

Linear time did not displace indigenous time concepts in Europe so much as it added itself to them in the life of the new institutions which made linear time socially relevant. As we have already seen, to the extent that people cared about time at all, their temporality was cyclical, organized in terms of binary oppositions (day/night, summer/winter, et cetera) between which time moved in pendulum fashion. ${ }^{31}$ As new institutional forms developed-industrial workshops, the state, contracts and courts-different forms of time multiplied as they were juxtaposed in contiguous social fields. Such proliferations continue today, in the West as well as the other places where different temporalities come into contact as social tensions-for example, work and family life, the market and faith, aspiration and consolation.

vincing in general, but controversial in detail; for additional data and discussion of these controversies, see D. Landes, The Revolution in Time (1983); J. Needham, W. Ling \& D.J. DeSolla Price, Heavenly Clockwork: The Great Astronomical Clocks of Medieval China (1960). In any event, L. MUMFORD, supra note 18, at 14-17, ascribes the symbolic power of the clock to its dissociation of time from human events; time-keeping became time-serving.

30. See J. LeGoff, supra note 20; R. TAWNEY, supra note 22, at 44-55; Thomas, Work and Leisure in Pre-industrial Societies, 29 PAST \& PRESENT 50-62 (1964).

31. See E. Leach, Rethinking Anthropology 124 (1961). 
If linear time dominates our public lives it is because its primary efficacy is in the construction and management of dominant social institutions, not because it is the only "kind" of time that is culturally available. Linear time in the West was popularized by the church, by monarchs, and eventually by other elites who found in an image of time's unidirectional progress the central symbol of their legitimacy. Linear time, however, cannot fulfill its own claims to redemptive completeness without borrowing from the other temporal idioms that express other, equally sacred meanings from other domains, for example, the idioms of cyclical time. Cyclical time idioms suffuse Western concepts of private life and personal life: birth and death, the generations, dust to dust, the ages of man, marriage, parenting-all of these cultural images invoke cyclical time.

Indeed, cyclical and linear time compete with each other in Western culture. Their clearest competition is in cultural notions of the individual life, which is itself an intersection of two domains: ideas about the creation of life (birth, maturity, aging, death), and other ideas about the meaning of life. Cyclical time offers the primary idiom of life's creation as the reciprocal of personal death. Linear time makes a person's life just another segment in the larger progress of time in relation to eternity (to the extent that modern secular thinking does not utterly conflate time and eternity). Cyclical time emphasizes substance in its constant alternation (in the Western case) between opposed and reciprocal states (for example, life and death, hot and cold, day and night). Linear time emphasizes historical form in its continual juxtaposition of equivalent intervals.

Both forms of time share and express a long Indo-European cultural tradition that stresses the reciprocal relationship of society and cosmos, the eternity of matter, the infinity of time and the inevitability of change, ${ }^{32}$ although they do so in substantially different ways. Where cyclical time makes death the source of life, linear time makes God the source of time. Where the infinity of time is represented as an unending cycle or pendular motion, it can also be expressed as an unending line. Where constant change can be conceptualized as cyclic, linear time expresses a unique cycle (the world being said to have been created only once, by God, a "big bang" or whatever) that is itself a manipulation of the idea of cyclicity.

Linear time does not so much replace cyclical time, as literally reform it within its same general framework. But the reformulation of time can be achieved only if the crucial differences among time's forms can be effectively suppressed. The difference between death as a source of life, and death as the marker of an ineluctable ending, or the difference between life as an event and life as a condition-these differences must somehow be blurred. By rendering the differences indeterminate, this blurring of

32. See B. Lincoln, Myth, Cosmos and Society: Indo-European Themes of Greation and Destruction 140 (1986). 
particular points of competition among forms of time can be effectively managed. Linear time involves two crucial kinds of indeterminacy-one in the construction of the lifetime (as reciprocal or interval), and the other in the representation of the completeness time claims to represent (linear versus cyclical infinity). Perhaps these are only two sides of the same conceptual coin, in that both involve the "sites" where the respective geometries of linear and cyclical time most conspicuously converge in the individual on the one hand and in ultimate things on the other.

The affirmative power of linear time is in its ability to resolve tensions among priorities, loyalties, and accountabilities. But such power is lost if rival temporalities lose their power to create tension. To put this another way, linear time can dominate a society only if its beneficiaries carefully manage the indeterminacies discussed here, loosening time's "line" to engage the widest possible array of human commitments, but tightening it again when the efficacy of public institutions is at stake. We will return to this idea later.

\section{Time, LAW and Other Institutions}

Although the discussion so far makes use of historical data, the analysis is not historical, but cultural. That is, it is about relationships among systems of ideas rather than about events and motives. Cultural analysts stress the self-referential aspects of systems of ideas, but this is not to say that ideas are born in vacuums. A single idea may have many expressions, and so anthropologists are as concerned with how principles of selection develop in relation to the myriad possible enactments of cultural propositions as they are with the propositions themselves. In the case of Europeans' popularizations of linear time, the context is important in shedding light on how the meanings of linear time have become what they are. Hence the discussion in the previous Section. This Section highlights three aspects of that context that have particular bearing on the modern meanings of law in the West.

First, the secularization of linear time-moving the clock from the church steeple to the palace turret-represented a major strategic innovation of medieval statecraft. In effect, by borrowing the church's idiom that situated time in relation to eternity, secular temporal discourse achieved a reification of society by locating the end of time outside of any individual or collective social experience. "Society" thus became a conceptual union of time and place (here is to there as now is to then). This analogy is by no means universal around the world, since its underlying premise (the differentiation of places in terms of the passage of time) is not universal. It is worth noting in passing that society reified in this way cannot escape at least a rhetorical commitment to "progress" as a way of connecting "societies" at different points in time. 
Second, secular monarchies eventually resolved the contradictions between an enduring kingship and a mortal king with the notion of "the king's two bodies," that is, differentiating between the office of the king and the occupant of the office. ${ }^{33}$ This conceptualization of incumbency is not universal, either, though it is by no means unique to Europe. ${ }^{34}$ Before the idea of the King's two bodies was established, the king had become the symbol of the state, as shown by the idea of treason, new in Edward III's time in England. ${ }^{35}$ Treason in England acquired statutory definition before any other crime (in 1352); that is, the symbolic status of the state was (and had to be) established before acts could be prosecuted in "its" name. The important point here is that this symbolic status was achieved by regularizing the temporal contradictions of kingship by embracing both the king's mortal person and the enduring kingship within a single institutional form. The scholarly assessment that Europe's legal development was revolutionary in the medieval period appears to be widely accepted. ${ }^{36}$

Third, by the time the modern period began, law had become the dominant image of conflict resolution, ${ }^{37}$ linking king and subject-at least hypothetically-in the integument of everyday life. Extensive changes in European legal institutions and law were but one element of wider patterns of social and cultural change. This was the era that saw the development of cities, ${ }^{38}$ major changes in church doctrine, ${ }^{39}$ and profound changes in the structure of the economy. By the end of the medieval period, Europe had the common law, written contracts, juries, academic law, and, more generally, a wider use of the law, in the prosecution and defense of individual interests. ${ }^{10}$ In any event, both legal institutions and their pattern of use at the end of the medieval period seem relatively more familiar to the modern eye than what preceded it. ${ }^{41}$

33. See E. Kantorowicz, The King's Two Bodies (1963).

34. See, e.g., J. Goody, Succession to High OfFice (1966).

35. See 3 W. HoldswOrTh, A History of EnGlish Law 287-89 (3d ed. 1927).

36. See, e.g., M. GibBs, Feudal Order 106 (1949). For a discussion of the development of English common law, see A. Harding, A Social History of English Law 13 (1966).

37. See J. Bossy, Disputes and Settlements: Law and Human Relations in the West 287 (1983) (discussing images of feud, charity, and law).

38. See C. Cipolla, Before the Industrial Revolution 143-49 (2d ed. 1980).

39. See, e.g., J. LeGoff, La Naissance du PuRgatoire 9 (1981) ("invention" of Purgatory).

40. See 1 M. BLOCH, supra note 29, at 113-20. The fifteenth century was "the golden age of litigation," Kagan, A Golden Age of Litigation: Castile 1500-1700, in Dispures AND SETTLEMENTS: Law and Human Relations in tHe West 145-66 (J. Bossy ed. 1983) [hereinafter DisPUTES AND SETTLEMENTS], so widespread had it become-and the most frequent litigant was the king.

41. Anglo-Saxon law was kin-based. See 1 F. Pollock \& F. Maitrand, The History of ENGLISH LAw BeforE THE TIME of EDWARD I 31 (2d ed. 1959). Land disputes were regularly resolved through trial by battle, A. HARDING, supra note 36, at 41 , and the blood feud persisted in northern Europe until "well into the medieval period." Wormald, The Blood Feud in Early Modern Scotland, in Disputes and SETtlements, supra note 40, at 101, 102. An early role of the church in local dispute settlement in sixth-century Gaul was to intervene to end blood feuds; records from this period also show the legal use of ordeals and oaths. See James, 'Beati pacifici': Bishops and the Law in Sixth-Century Gaul, in Disputes AND SetTlements, supra note 40, at 25, 32-33. The ancient law of Belgium and northern France distinguished not personal rights but family rights. 1 E.M. 
The common law, which developed at this period, in some respects reflects perfectly a logic of linear time, in its reliance on precedent, its commitment to reform, and its acknowledgment of individual persons and rights. But the common law also involves larger claims beyond linear time. Reasoning by analogy to precedent creates a false historicity in that it perpetually reclaims the past for the present: in theory, a dispute in 1989 can be resolved by reference to cases from 1889 or 1389. "The law" thus accumulates, but it never passes; at any instant, it represents a totality. It is by definition complete, yet its completeness does not preclude change. It is a human achievement, yet, by its reversible and lateral excursions, and by its collective voice, it is not identifiably the product of any particular individual or group. Symbolically, it stands at the border between the two great zones of Indo-European thinking - the human-made (the anthropogonic) and the divine (cosmogonic) -and is nourished by the indeterminacy of the distinction between events in linear time and possibilities (all-times). ${ }^{42}$

$\mathrm{Law}^{43}$ has a mythic dimension, in its self-totalization, its quality of being in time (in that it is a human product) but also out of time (where did it or does it begin or end?) and in its promise of systematic yet permutable meaning. This myth is essentially a temporal one. Specifically, the law's implicit claim is to invoke the total system of its own distinctions simultaneously in a way that both individualizes subjects/citizens and orients them toward particular forms of action. ${ }^{44}$ That such symbolism has been effective only since the late Middle Ages reveals the continued capacity of modern society to generate myth. For the myth to remain viable, the law must continually reiterate the distinctions between law and interests, the ephemeral and the enduring, the political and the sacred.

Meijers, Études D'Historre du Drort 228 (1956). The same could be said of England, where the early state had to compete against the family. See 1 F. Pollock \& F. Martland, supra, at 31. After the Normans appeared concepts of absolute liability, id. at 54, both apparently successfully directed at strengthening and extending the power of the king over a hostile countryside. The regularization of law in England under the Normans is credited with resolving serious problems of disorder which had persisted since the break-up of tribal kingdoms in the eighth century. M. GiBBs, supra note 36 , at 60 .

42. Berman argues that the critical formative issue in modern Western law is its origins in canon law, and the canon law's embedded premises about the contingencies of the Last Days. Thus, the modern nation would involve conceptions of transcendence. H. BERMAN, LAW AND REVOLUTION: The Formation of the Western Legal Tradition 49-119 (1983).

43. I use the word "law" in the broad sense here and below, acknowledging distinctions to be drawn in some contexts (but not, I think, in this Article) among the common law, constitutional law, and statutory interpretation. See Monaghan, The Supreme Court, 1974 Term-Foreword: Constitutional Common Law, 89 HaRv. L. Rev. 1, 4-5 (1975). In general, my usage emphasizes cultural ideas about law, which may or may not be descriptive of legal operations.

44. I take this definition of myth from the work of Claude Lévi-Strauss. See, e.g., C. LÉviStrauss, The Jealous Potter (1988). 


\section{The Law and Its Times}

So far, this Article has focussed on general issues of social structure, temporality, and law in Europe and the West. In effect, the argument has been that, given the social context in which linear time was received and popularized in Europe, linear time is "about" the crucial indeterminacies between the individual lifetime and the enduring public institutions which claim an individual's consciousness and, potentially, service. These indeterminacies are essential in that they go to the very crux of what linear time is "for" in the West, that is, the redemption of individual lifetimes through participation in the social and cosmic order. Further, they must be preserved as indeterminacies for the system to work. In the West, it is the law's cultural role to do just this. The law represents itself in ways that situate it at precisely these indeterminate points, resolving conflicts one at a time while gesturing toward the totality of all resolutions of all hypothetically possible conflicts. (The contrast at issue in that gesture is that of an actual human being, as opposed to the printed words "plaintiff" and "defendant.") Western cultural notions of law give it this mythic aspect, which is by no means universally the "property" of the law.

Let us turn now to a modern, familiar social field in which these themes are expressed, negotiated, and reproduced. The remainder of this Article offers an extended illustrative case, and that is in the general domain of judicial succession at the United States Supreme Court. I have chosen the Supreme Court because it is the highest court of the nation, and so by its very nature must be concerned with strategies for defining and protecting its own unique status as the ultimate national legal authority. I focus on succession because it is there that anthropologists look to find the most explicit cultural definition of office in relation to social structures and groups. An office is a scarce resource, and the cultural concerns that surround its allocation are highly revealing of indigenous conceptions of social structure. ${ }^{45}$ Eligibles may be determined in any number of ways-from primogeniture to battle to popular election and so on-but they are determined somehow, and that is key. Installation may be marked with ceremony, or it may not, and these rituals are laden with significance for anyone interested in the wider meanings encoded in systems of statuses and roles. The ethnological literature is helpful on each of these points.

Judicial succession is particularly relevant to the general problem of this Article in that it is precisely in succession that multiple temporalities-of the law, personal lifetimes, and public lives-and their indeterminacies must be worked out. I must stress that I refer here to cultural

45. See J. Goody, supra note 34 , at 2 . 
representations of succession-the ideal-and, eventually, the sorts of practical problems that those ideals generate.

The law in the United States (but not only there) must juggle at least three essentially different forms of time. First, at least in public life, Americans inherit a dominant temporal culture that stresses the linear, infinite nature of time and simultaneously the finite irreversibility of any individual's lifetime. This means that while modern secular thought suspends the beginning and end points of time as indeterminate, it nonetheless celebrates them in the "certainty" of time's passage from past to present. No two moments repeat, and the passage of time is both regular and regulated according to international standards. ${ }^{46}$ This is the kind of time of ethnic and national histories. ${ }^{47}$

But a second temporality is in the law itself. As we have already proposed, the law involves the constant expansion of a linear time framework (in the production and use of "precedent," for example, but not only by extending the "time-line" further forward or back). This is a form of timelessness, or, more accurately, all-times, a form of time which stipulates time as social, but not with geometric metaphors. Importantly, the endpoint of the law in time is neither fixed nor envisioned. Significantly, though, it is symbolically coterminous with a national social life, and it represents that national life in temporal terms. ${ }^{48}$ As mentioned earlier, the mythic aspects of law that inhere in this conception of things set the law apart from the many other institutions in which conflicts can be resolved and the normative repertoire adjusted. The mythic aspects of the law that inhere in its special expanded temporality are essential to its claims to neutrality, both in the sense of being capable of balancing competing interests, and engaging in a values discourse. ${ }^{49}$ If linear time is the time that connects individual interests to the state, then neutrality in a linear time idiom requires a symbolism of all-times. ${ }^{.0}$

The time of the law is distinctive not only for its cumulative aspect, but also because it is reversible. The law exists in reversible time in two senses, that is, in that prior decisions can control present ones, and also in

46. See Zerubavel, The Standardization of Time: A Sociohistorical Perspective, 88 AM. J. Soc. 1 (1982).

47. See Chock, The Outsider Wife and the Divided Self: The Genesis of Ethnic Identities, in Discourse AND THE Social Life of MEANing 185-204 (P. Chock \& J. Wyman eds. 1986); Kahn, Reason and Will in the Origins of American Constitutionalism, 98 Y ALE L.J. 449, 509 (1988). For a discussion of neutrality in the ethnology of law, see Greenhouse, Mediation: A Comparative Approach, 20 MaN 90-114 (1985).

48. See Kahn, supra note 47, at 508-16.

49. That justices themselves must struggle with the meaning of neutrality is also relevant here. See Kahn, The Court, the Community and the Judicial Balance: The Jurisprudence of Justice Poutell, 97 YALE L.J. 1 (1987).

50. Neutrality is defined differently around the world, as well as in different situations in the same context, along several converging continua: knowing or not knowing the parties, having an interest in the outcome or not, participating as an equal or as a superior-the anthropological literature on law offers multiple examples of each of these possibilities. 
that prior decisions can be reversed. The reversible aspect of the law is another important hallmark of its mythic nature. It symbolically underscores its claims to transcend any particular era or individual's life (more on this below). It also symbolically connects the law to nature itself-that peculiarly reasoned and authored nature of the late eighteenth century that made God, law, reason, and nature share a single set of principles. ${ }^{51}$ I will argue later that the law's particular temporality generates the key symbols of the American judiciary-even though the law has many sources, and modern skepticism has challenged the specifics (though not the symbols in the civic culture) of the enlightenment view of things. ${ }^{52}$

But finally, there is a third kind of time embedded in the law, and that is the judges' own lifetimes. In stark contrast-the starkest possible-to the law's self-totalizing, reversible, and boundless accumulations, judges' lives are finite. This problem is by no means unique to judicial succession in the United States. Any conception of time that has shape and direction focuses attention on the incongruities of sustaining the legitimacy of the system while vesting individuals with its authority. In the special time of the law, which is multidirectional rather than nondirectional, qualification becomes a particular cultural dilemma as well as a practical problem that goes to the very heart of the judiciary's cultural legitimacy.

In the process of filling a vacant seat on the Supreme Court, all three of these times come vibrantly into play. A vacancy is ordinarily caused by the death of the incumbent, or anticipated age- or health-related decline of competence. Life tenure potentially secures long service from an individual Justice, and yet his or her performance can involve no conspicuous apprenticeship. The new Justice will be selected by the two "other," political branches of government, and is in itself a partisan, if not political, event. ${ }^{53}$ The special temporal symbolism of the law requires a special "kind" of person, one who will find the law, not make it; know the law, but not preach it; be a representative of the national community, but have no causes of his or her own. These three temporal charters are by no means easily reconciled. Their reconciliation is possible only with the deft management of essential temporal symbols, that is, by downplaying or

51. M. Horwitz, The Transformation of American Law 1780-1860, at 7 (1977).

52. Ferguson notes that this particular equation (linking law, reason, and nature) emerged in American culture only after the Revolution. R. FERGUSON, LAw AND LETTERS IN AMERICAN CuLTURE 15-16 (1984). By the time Chief Justice Marshall retired in 1835, the Supreme Court had become "the great oracle of Americanism." Id. at 23.

53. The fact that the confirmation hearings for Supreme Court nominees are now televised, and widely viewed, reinforces several aspects of the process from a cultural perspective. As Gitlin suggests in his discussion of the impact of the televised Watergate hearings, public participation in the process via television tends to sharpen the cultural distinction between an office and its incumbent. $T$. GITLIN, Watching Television 31 (1986). Yet the media "transform the great silence of things into its opposite" by means of a narrative of "what's-going-on." M. DE CERTEAU, ThE PRACTICE of EVERYDAY LIFE 185 (S. Rendall trans. 1984). This is radically at odds with the public silence the Justices conventionally preserve about the development and negotiation of judicial opinions. 
suppressing altogether aspects of a judicial "career" that entail becoming. It is in becoming a judge that any tensions between individuality and a judicial persona would be most evident. ${ }^{54}$

\section{Law, Life, and Time}

Regular succession to office calls not only for institutionalizing the principles by which competition for office can be controlled (this is what succession means), but also for sequencing eligibility for office. Another way of stating this is that we speak of "succession" when it is a question of the incumbent's fitting the role, rather than the other way around. The ethnological literature offers highly diverse examples of modes of succession and their accompanying ritualizations..$^{\mathrm{s}}$

Before reopening the cross-cultural questions, though, we must consider what sort of person is culturally considered to be qualified for the Supreme Court. ${ }^{8 B}$ The answer would not stir much controversy; what follows is literally a textbook definition:

One, demonstrated judicial temperament. Two, professional expertise and competence. Three, absolute personal as well as professional integrity. Four, an able, agile, lucid mind. Five, appropriate professional educational background or training. Six, the ability to communicate clearly, both orally and in writing, especially the latter. ${ }^{.7}$

Several things are striking about this set of criteria: first, they are presented as if they describe an exceptional individual, yet they evoke attributes that one might assume are widely and positively valued in society. Second, the list is evenly balanced among general statements of professional experience and personal attributes that are not aspects of experience. Third, the description implies that a judicial temperament is reinforced by the ability to reason; furthermore, while communication skills are clearly important, it is not ordinary social conversation that is key, but "especially" one's writing ability. Murphy offers a metaphor for this personal and professional elite when he refers to the Justices' "performance of their priestly duty of expounding the meaning of that holy writ [the Constitution]." ${ }^{\prime 8}$ The metaphor is perhaps at the heart of the matter: in the United States, the judiciary is the only robed branch. The robes (like those of American academics in procession) are those of (medieval) clerics.

54. Kantorowicz describes parallel debates over kingship in ancient Greece, as to whether the person who becomes king does so by receiving grace at the moment of installation, or by imitating the divine. E. KanTorowicz, supra note 33 , at 500 .

55. See infra text accompanying notes 61-69.

56. Again, I must stress that this is not the same as asking what sorts of persons have actually been considered for the Supreme Court; this article is about idealizations and symbols.

57. H. Abraham, Justices and Presidents: A Political History of appointalents to THE SUPREMe Court 4 (2d ed. 1985).

58. W. Murphy, Elements of Judicial Strategy 16 (1964). 
In effect, in terms of the symbolic claims of their office, Justices must literally embody neutrality; they are literally "judicial bodies." That their relationship to the law is metonymic rather than metaphoric implies important cultural constraints on the notion of representation as an aspect of the judicial role. In the case of the Supreme Court, the kind of neutrality that is culturally valued is a very particular one, in that the Justices are accountable "to the people" but in a way that precludes any legitimate scope for the expression of their own interests or personal views. Indeed, they are "supposed" to have no interests; this renunciation of particular private interests symbolically inverts to become, in effect, an embrace of all public interests. ${ }^{5 \theta}$ The alternative (renunciation as other-worldly) would contradict the other stipulations that a Justice be an exemplary individual without being a hero. A Justice should reason, without the exercise of will, ${ }^{60}$ a Justice must be the law, but he must also be society without representing either. Such are the symbolic prescriptions of the judicial office.

While the prescription for eligibility to the Gourt clearly demands an exceptional individual, it is mute on the question of how and when an individual comes to be inscribed with these qualities. This is an important cultural silence: at stake in it are other, larger questions about the nature of social life. For example, if Justices are literally to be found, then the implication is that there is a natural hierarchy of men and women that makes some fit for service and others not, and the authority and power of the President and Senate are symbolically downplayed. On the other hand, if Justices are made at the moment of their nomination-if it is then, and only then, that their renunciation of private interests takes place-then the conceptualization of the law is democratized and the authority and power of the President and Senate to select the Justice are symbolically emphasized. This is something of a dilemma for a society culturally committed to ideals of egalitarianism as well as the equality of the three branches of government. In effect, the time of the nation (linear, progressive time) and the time of the law (linear, cumulative time) compete for symbolic dominance over the process.

The installation of new Justices is so minimally ritualized-American civic ritual is characteristically truncated-that one must look elsewhere for signs of how the explicit negotiation of the law's multiple temporalities might proceed. Here, the ethnological literature is helpful, particularly where the temporal indeterminacies of law are roughly congruent. Such

59. See Kahn, supra note 49 , at 56-57.

60. Id. at 4-5. Kelman develops Unger's discussion of the distinction between desire and reason in liberal thought; desire individuates and reason universalizes. M. KELMAN, A GuIDE To CRITICAL Legal Studies 65 (1987). Later, Kelman relates this world view to a vision of law and truth as being beyond history. Id. at 229. See also Mensch, The History of Mainstream Legal Thought, in The Politics of Law: A Progressive Critique 19-26 (D. Kairys ed. 1982). 
congruence can be found in the traditional ritual chieftainships of central and western Africa, which also symbolically addressed incongruities among simultaneous temporalities, in ways that make their juxtaposition to American Justices productive. A brief excursion follows.

Chiefs, who ordinarily were members of a royal or chiefly clan or lineage, were understood to be otherwise ordinary mortal men. The chiefship, on the other hand, was associated with the regulation of the rains and other enduring natural cycles. Thus, the two salient temporalities were those of individual lifetimes and the larger cyclical idioms that expressed the society's relationship to nature. ${ }^{61}$ Furthermore, at least among the Bashu of Eastern Zaire, the chiefship itself (as opposed to the chief) marked the cycles of time. When the ritual chief died, or failed to ritually protect the land, pollution (which is always present) accumulated along with other negative social effects, and famine resulted; in practice, the one was literally the sign of the other: "The power of chiefship . . . is thus seen as fluctuating through time. It is, in fact, viewed as an almost organic substance that grows, declines, and is reborn. . . . Thus the waxing and waning of the land, cycles of plenty and famine, are directly tied to the waxing and waning of chiefship." ${ }^{62}$ The role of the ritual chief was complex; at its core, he absorbed the pollution that otherwise would have poisoned the community by fixing it in his own body.

Central African chiefs came to their offices by a combination of factors, both ascribed and achieved. While they might become eligible for the chiefship by virtue of their birth, their actual candidacy was a function of their performance skills in the conduct of the community's affairs. ${ }^{63} \mathrm{~A}$ central political arena (where such skills could be appropriately displayed) in traditional villages was the court, where royal representatives, or the king himself, heard disputes in a public forum. ${ }^{64}$ Chiefdoms and kingdoms identified strongly with their own law; many indigenous African cultures had an explicit cultural category for law. ${ }^{65}$ The law and the social existence of the community were symbolically coterminous, in contrast to power, which was the property of the royal lineage or the kingship itself. $^{63}$

61. See M. Fortes, Religion, Morality and the Person: Essays on Tallensi Religion 94 (1987); R. Packard, Ghiefship and Cosmology: An Historical Study of Political ComPETITION 24-32 (1981).

62. See R. PACKARD, supra note 61 , at 31 .

63. See J. Comaroff \& S. RoberTs, supra note 6; M. ForTes, supra note 61, at 87; Jones, Chiefly Succession in Basutoland, in Succession To High OfFICE 57, 61 (J. Goody ed. 1966); Southwold, Succession to the Throne in Buganda, in id. at 82, 91-92.

64. See M. Gluckman, The Judicial Process Among the Barotse of Northern RhodeSIA 1-34 (1967).

65. See, e.g., id.; J. Comaroff \& S. RoberTs, supra note 6.

66. See Southwold, supra note 63 , at $82-126$.

I use the past tense here because it is temporally accurate, not because the nature of "traditional" or indigenous law is in any way a settled question wherever it has been described. Chanock examines at length the indigenous referents of contemporary "customary" law in Malawi and Zambia. M. 
Thus, at stake in succession were not only the symbolic efficacy of the law, but also the literal health of the chiefdom-perhaps each was the corollary of the other. The investiture ceremony among the Bashu unfolded around the central imagery of the new ritual chief's social rebirth. ${ }^{67}$ The candidate was given a funeral, and then a surrogate mother, and finally a new social identity as ritual chief. Indeed, throughout central and west Africa the dominant mode of the investiture ceremony appears to have been that of the funeral; at death, the subject-candidate died, the chief was born. ${ }^{68}$ These societies addressed the dilemma of the incumbent's single lifetime in relation to the law by symbolically dividing it, letting the ordinary man with his private interests die, and setting the stage for the birth of the new ritual chief who served the entire community. He was symbolically-which is to say literally-not the same person.

The installation ceremony among the Bashu also addressed the other dimension of the law's temporality, and that is its identity with the ebb and flow of nature and society. To be more accurate, that ebb and flow is the circulation of pollution, from the bush to the village and back again. When all is well, the ritual chief kept the pollution at bay by means of his ritual expertise and his ability to absorb (literally to incorporate) the pollution that would otherwise poison the community. The installation ceremony commented on this theme in detail. Since the installation followed the death of a ritual chief who was by definition polluted by virtue of his performance of office, that pollution had to be discharged in a purification rite. Eventually, the new chief, as part of his ceremonial, took on this pollution and transferred it to the bush, leading the way to his own purification. Pollution could not be purified but only ritually displaced; hence the importance of maintaining the succession of the ritual chief, ${ }^{69}$ and the succession ritual itself.

Let us return now to the American case, reiterating briefly some parallels with the African contexts briefly described above, and then some contrasts. First, in both the American and African contexts, law is equated with social health. ${ }^{70}$ Second, in both contexts law is distinguished from.

Chanock, Law, Custom and Social Order: The Colonial Experience in Malawi and ZAMBIA (1985). Moore challenges the notion that customary law was in any sense of the word traditional or indigenous. S. MOORE, SOcial Facts and Fabrications: "Customary" LaW ON KiliMANJARO, 1880-1980 (1986).

67. I refer particularly to the Bashu because their ceremony is described in rich detail by Packard. See R. PACKARD, supra note 61, at 34-42.

68. In addition to Packard, see Forde, Death and Succession, in Essays ON THE RITUAL OF Social Relations 89-123 (M. Gluckman ed. 1962).

69. This is also true among the Tallensi and Ashanti. See M. Fortes, supra note 61, at 94.

70. There is also an interesting difference at this juncture. Where the African cultures do not define conflict in itself as antisocial or asocial, they do define the community in terms of controlling its antithesis, that is, nature. American culture, too, locates the antithesis of community in nature. In the American case, however, it is conflict that is considered antisocial or asocial, a sign of the "untamed" and therefore, symbolically devalued. See Greenhouse, Courting Difference: Issues of Interpretation 
politics, even though legal officials might in practice be important political actors. Third, legal officials, by their office, mark their distinction from the rest of the community from which they have come. Finally, both systems address parallel temporal incongruities in that the incumbent of a legal office is mortal, yet the law is identified with a larger temporality. In the African case, this larger temporality is cyclical. In the American case, it is cumulative and reversible.

In contrast to American judicial succession, the African succession rituals referred to here illuminate a cultural armature that is less evident in the American setting. The African succession rituals negotiate specific tensions between the incumbent's lifetime and the time of the law, in effect, by separating his person from his body. The office of the ritual chief begins with the birth of the new chief-a second birth that brings him to the world as chief. His body is unchanged, but his person is now the chief who occupies and uses his body differently than he did before. The chief can die; the chiefship is time itself.

In the American context there is no public imagery of rebirth to mark the formation of a new Justice-of new justice. To do so would be symbolically dangerous, as I have already mentioned, as it would denote the subordination of the judiciary to the first and second branches, and of law to politics. The Justices are not politically accountable, yet remain accountable by the same indirection as the Tallensi chiefship: the Tallensi chief is accountable to the ancestors, and-only through them-to their living clansmen. ${ }^{71}$ Similarly, the Supreme Court Justices are accountable to the American people-an ancestral, or mythic/historical invocation-but not to particular people. The Justices no longer live in a single time dimension, but in all the times that have been and are the law. This is one sign of their altered personhood, and it is consistent that they conventionally be held to a public silence, that they forbear from narrating their own decisions and indecisions as personal events, and that their primary discourse be written, not spoken. And, as has already been noted, they must selectively leave the world.

Another sign of their changed personhood, of their second birth-or is it a first death in the American case?-is the subtle transformation of the meaning of their physical bodies. The illnesses of the Justices are strikingly downplayed in the press in relation to those of the president, for example. Their gender, until Justice O'Connor's appointment, was unmarked (male). Their race, until recently, was unmarked (white), and now the refraction of this standard creates new generic markers: the public refers to "the Jewish seat," "the black seat." Their bodies are seats,

and Comparison in the Study of Legal Ideologies, 22 LAw \& Soc'y REv. 687-707 (1988).

71. M. ForTES, supra note 61, at 101. 
just as the African chiefships are stools. ${ }^{72}$ The only public relevance of their bodies, in other words, is in their occupancy (or not) of a seat. This is not ordinary mortality, with maturation and decline; it is the mortality of gods, as if Justices were born in full mature form at the bench and died in full stride. Here, retirement is metaphorical death. The life of a Justice is no longer the lifetime of the man or woman who became that Justice. All aspects-biographical and political-of becoming a Justice are symbolically suppressed. Those aspects are precisely the ones that would (though they cannot) resolve the indeterminacies linking the times of the individual, the law and the nation in relation to the power of the presidency and the Congress.

To continue the foregoing example, why did the Bashu resolve the problem of temporal indeterminacy with a sequential doubling (layman/ chief), while American Justices are culturally denied not only their former social selves, but also their own public initiation? Perhaps one answer lies in a repetition of the question. The Bashu could construct a public ritual of becoming, while the Americans cannot. Why, then, was the transition to chiefship so explicit for the Bashu, and so tacit for the American Justices? I believe the answer has to do with their respective cultural conceptualizations and institutionalizations of politics and social order.

In the case of the Bashu, as already noted, the ultimate order of things moved through the chief, in his role as a central point of dispersal of local pollution. The installation ritual equated the chiefship with this role. Without the chief, there was no cosmic order, and when disorder accumulated, it was supposed to be a sign of the chief's suspended legitimacy. In the American case, Justices invoke a parallel image of serving as "an instrument" of the law ${ }^{73}$ but with the difference that supposedly coordinate branches of government also create law on very different terms. The threat of disorder in the American judiciary is conceptualized as the overwhelming of the judicial by the political. If the American judiciary avoids articulating its own initiations, it is perhaps because to do so would be to offer too unambiguous a gesture toward the other branches. Those are the branches of events, quid pro quos, representation and fixed terms of office, that is, of linear time; the judiciary is the branch of all-times, demanding of Justices something between renunciation and charisma. ${ }^{74}$

Yet, part of the story of the world would be the story of rituals and meanings invented and lost. To turn to the example at hand, if there ever comes a day when new Supreme Court Justices are inaugurated in a public festival, or when Presidents are not, it will be a sign of a profound

72. Id. at 88 .

73. This image was Chief Justice Marshall's. See J.B. WhITE, WhEN Words Lose Therr MEANing 255 (1984).

74. See J.G.A. Pocock, supra note 1, at 243 (discussion of charisma and tradition as entailing different temporalities). 
revolution in both the structure of American government and the belief of the people in the possibility of justice under anything like present terms.

\section{Conclusion: Culture AND Justice}

In this Article, the central theme has been the connections-cultural connections-between Western conceptions of temporality and the ways in which the law (in the broad sense of the term) organizes and reproduces an essentially temporal myth. Linear time, which is the cultural preserve of national histories and the public institutions that comprise them, dominates those institutional settings only to the extent that the people who inhabit them (whether managers or employees, presidents or citizens) believe that linear time has a transcendent reality that allows it to absorb all the other temporal idioms that also suffuse daily life, and are potentially its rivals. The Western cultural capacity for that belief was established a thousand years ago, or longer, when institutional and social structural changes gave linear time a path from the sacred domain to the domain of the everyday. That capacity for belief is reproduced in the juxtaposition of institutional forms and temporalities which constitute everyday experience in the modern world. "The law" is cultural not only, or not first, in its patterned processes and outcomes, but in its constitution in multiple temporalities and their indeterminacies. Specifically, law-as an idea-carries cultural force because it engages these temporalities and their critical incongruities so directly.

By exploring contemporary cultural representations of the judiciary, one can find fresh traces of the journey that linear time makes from the sacred to the secular, and back again. In the ordered system of symbols that inhere in the Justices' idealized roles, the multiplicities of time and time's rival possibilities of order find renewed expression. It is beyond the scope of this Article to resolve the question of whether Supreme Court Justices live out the symbols that to some extent define them, or whether they should. Those are important questions, but of an entirely different character than the one this essay addresses. That question is about the means modern society has at its disposal for conceptualizing justice. If "justice" is constituted in a juxtaposition of temporalities-times and alltimes-then "justice" implies both a progress for the world and a critique, that is, an imagined vantage point from which history itself might be judged. While legal actors' claims to legitimacy might be conventionally or historically cast in terms of the connection between reason and fixed (timeless) truths, the cultural interpretation developed in this essay has situated the cultural force of the law in its engagement and resolution of multiple, mutually contesting temporalities with the potential for posing rival claims on social actors. To say that the law is cultural does not by itself dismantle the force of the idea of justice, since just at the point 
where cultural and political inquiry would intersect, justice and Justices return to the separate temporal domains which, in cultural terms, give them life. 
